\title{
Effect of Combining Ultrasound and Mild Heat Treatment on Physicochemical, Nutritional Quality and Microbiological Properties of Pineapple Juice
}

\author{
Camel Lagnika1,2*, Yann C. S. Adjovi1,2, Latifou Lagnika², Fructueux 0. Gogohounga1, \\ Ornella Do-Sacramento ${ }^{1}$, Raoul K. Koulony ${ }^{2}$, Ambaliou Sanni ${ }^{2}$ \\ ${ }^{1}$ Ecole des Sciences et Techniques de Conservation et de Transformation des Produits Agricoles de Sakété, Université Nationale \\ d'Agriculture, Porto-Novo, Bénin \\ ${ }^{2}$ Unité de Biochimie et de Biologie Moléculaire, Laboratoire de Biochimie et des Substances Naturelles Bioactives, Faculté des \\ Sciences et Techniques, Universtité d’Abomey-Calavi, Abomey-Calavi, Bénin \\ Email: ${ }^{*}$ lacamvet@yahoo.fr
}

How to cite this paper: Lagnika, C., Adjovi, Y.C.S., Lagnika, L., Gogohounga, F.O., Do-Sacramento, O., Koulony, R.K. and Sanni, A. (2017) Effect of Combining Ultrasound and Mild Heat Treatment on Physicochemical, Nutritional Quality and Microbiological Properties of Pineapple Juice. Food and Nutrition Sciences, 8, 227241.

https://doi.org/10.4236/fns.2017.82015

Received: January 16, 2017

Accepted: February 18, 2017

Published: February 21, 2017

Copyright (c) 2017 by authors and Scientific Research Publishing Inc. This work is licensed under the Creative Commons Attribution International License (CC BY 4.0).

http://creativecommons.org/licenses/by/4.0/ c) (i) Open Access

\begin{abstract}
Increasing consumer awareness regarding the health benefits of different nutrients in food has led to the requirement of assessing the effect of food processing approaches on the quality attributes. The present work focuses on understanding the effects of ultrasound (US) processing, mild heat pasteurization $\left(65^{\circ} \mathrm{C}\right.$ for $\left.15 \mathrm{~min}\right)$, thermal pasteurization $\left(80^{\circ} \mathrm{C}\right.$ for $\left.15 \mathrm{~min}\right)$ and their combination on physicochemical, microbiological properties and nutritional quality of pineapple juice through 60 days of storage at room temperature. Ultrasound treatment showed significantly lower browning degree. Ultrasound followed by ultrasound combined with mild heat pasteurization (UMP) treatments was effective in retaining the total phenolic content of pineapple juice as compared to the thermal treatment or the untreated juice sample at room temperature during 60 days of storage. Thermal pasteurization (TP) followed by ultrasound combined with mild heat pasteurization (UMP) and ultrasound (US) treatment, in increasing order, was found to be effective in delaying microbial growth in pineapple juice. This study demonstrates that ultrasound combined with mild heat pasteurization treatments could be able to effectively inactivate the microorganisms and pectin methylesterase in pineapple juice whilst preserving relatively high amount of phenols.
\end{abstract}

\section{Keywords}

Ultrasound, Mild Heat, Pineapple Juice, Browning, Total Phenolic Contents 


\section{Introduction}

Considerable attention has been focused on vegetable and fruit juices recently due to the presence of health promoting compounds in the juices and ease of consumption especially for packaged juices. Juices play an important role in the daily nutrition and provide essential supplements. Pineapple (Ananas cosmosus) is one of the most important tropical fruits. Pineapple juice is famous for its sweet and sour taste as well as beneficial health compounds. The protective effects of this product have been associated with the presence of antioxidant compounds [1] [2], which include ascorbic acid, bromelain, carotenoids, phenolic compounds and flavonoids among others [3]. Besides, it contains sufficient amount of minerals especially potassium and calcium. Being rich in antioxidants, pineapple juice has been proven to reduce the incidence of cardiovascular disease and some chronic and degenerative diseases associated with oxidative damage [4]. Bromelain is the major proteolytic enzyme complex that is found prominently in pineapple [5]. Hale et al. [5] also reported that proteolytic activity is required for the therapeutic effect of bromelain. Bromelain exhibits therapeutic and pharmacological effects such as anti-inflammatory tumour growth modulation and aids in digestion [6] [7].

Spoilage in pineapple products is not only encountered by microbial contamination but also by enzymatic degradation which is generally not accepted by the consumer [8].

Thermal pasteurization is a common process used to inactivate pathogenic bacteria and some enzymes in juice. However, due to the high temperature used in the process, the nutritional and sensory properties of the pasteurized juice might be somewhat altered [9]. Thus, there is an increased demand for new methods that will have a reduced impact on the nutritional content and the overall food quality. Some non-thermal pasteurization methods have been proposed during the last couple of decades, including high hydrostatic pressure, high pressure homogenization, pulsed electric field, radiation processing, and ultrasound [10] [11]. These emerging techniques seem to have the potential to provide "fresh-like" products, and preserve nutritional and organoleptic qualities and safe fruit juices with prolonged shelf-life.

From scientific literature, it is apparent that some individual non-thermal methods are effective to inactivate microorganisms or reduce the log colony forming units (CFU) while not adversely affecting the sensory and nutritional quality.

Sonication (ultrasound) treatment, which is an emerging technology that is considered to be inexpensive, simple, reliable and environmentally friendly, has been studied for use in several applications including fruit juice processing [12] [13] [14]. According to O'Donnell et al. [15] ultrasonic processing of fruit juices has the minimal effect on the quality of fruit juices such as orange juice [14], guava juice [16] and strawberry juice [17]. Ultrasound alone and/or in combination with other techniques has been reported to be effective against Escherichia coli in model fluids [18], as well as apple cider [19] and against Listeria monocytogenes in apple cider [20]. Piyasena et al. and Jiranek et al. [21] [22] have re- 
ported an extensive analysis of the potential of ultrasound for inactivation of food borne pathogens.

Despite the numerous published reports on the effect of non-thermal treatments combined with mild heat pasteurization on fruit juices, there is a lack of information on pineapple juice. There is a need for alternative combined treatments that can preserve quality properties of pineapple juice. Therefore, the aim of this study was to evaluate the effect of mild heat pasteurization, thermal pasteurization, ultrasound, and their combination on the physico-chemical, microbiological properties and nutritional quality of pineapple juice during storage.

\section{Materials and Methods}

\subsection{Sample Preparation}

Freshly harvested pineapples (Ananas comosus) were purchased from a local market at Cotonou, Benin. The obtained fruits were washed, peeled and pressed mechanically in a household juice extractor. The extracted juice was further filtered using a vacuum filtration unit through Whatman filter paper No.1 and then stored in an aseptic manner and further subjected to different thermal and non-thermal treatments.

Pineapple juice obtained was divided into five groups, and each group was samples $(250 \pm 5 \mathrm{~mL})$ at least three times using glass jars.

\subsection{Experimental Design}

The different groups were subjected to the following treatments.

Untreated groups are the fresh pineapple juice without any treatment was used as control (C).

Water bath having a polycarbonate basin was used for pasteurizations treatments of juices. The Biobase water bath had special features such as thermostatic control, temperature resistance till $120^{\circ} \mathrm{C}$, operating temperature range of $25^{\circ} \mathrm{C}$ $100^{\circ} \mathrm{C}$ with accuracy of $\pm 0.3^{\circ} \mathrm{C}$ and electric supply of $220 \mathrm{~V} / 50 \mathrm{~Hz}$. For mild heat pasteurization (MP), juice $(250 \pm 5 \mathrm{~mL})$ was transferred into a clean sterile closed glass jar and was pasteurized at $65^{\circ} \mathrm{C}$ temperature for $15 \mathrm{~min}$. On the other hand, for thermal pasteurization (TP), juice $(250 \pm 5 \mathrm{~mL})$ was transferred into a clean sterile closed glass jar and subjected to heat treatment at $80^{\circ} \mathrm{C}$ for $15 \mathrm{~min}$. The jars were kept for constant shaking at $100 \mathrm{rpm}$ to obtain homogenous conditions inside the samples throughout the treatment. Samples were cooled immediately after the heat treatment and stored at room temperature $\left(26^{\circ} \mathrm{C} \pm 2^{\circ} \mathrm{C}\right)$ till further analysis.

Ultrasound (US) treatments were carried out using Bioblock Scientific, Vibra-cell 75,115 (with probe diameter of $10 \mathrm{~mm}$ ) at constant power of $500 \mathrm{~W}$ and frequency of $20 \mathrm{kHz}$ for $15 \mathrm{~min}$. The temperature was maintained below $65^{\circ} \mathrm{C}$ using an ice bath around the reactor. The temperature of the juice was monitored using a thermometer and it was ensured that the temperature was below $65^{\circ} \mathrm{C}$.

Juices were also treated in a combined operation using ultrasound and mild heat pasteurization (UMP). Ultrasound parameters were set at the same opti- 
mized values as mentioned earlier. After ultrasound treatment, the juice was pasteurized at $65^{\circ} \mathrm{C}$ for $15 \mathrm{~min}$.

The processed juice was stored at room temperature $\left(26^{\circ} \mathrm{C} \pm 2^{\circ} \mathrm{C}\right)$ and used at regular intervals for different analysis. Measurements and analyses of the juices were performed on the following days of storage period; 0 , 15th, 30th, 45th and 60th day. Three samples were prepared for each treatment. The experiment was done in triplicates.

\subsection{Physico-Chemical Analyses of Pineapple Juice}

\subsubsection{Determination of $\mathrm{pH}$, Titratable Acidity (TA) and Total Soluble Solids (TSS)}

The $\mathrm{pH}$ of the pineapple juice was measured using hand digital $\mathrm{pH}$ meter (Eutech Instruments, $\mathrm{pH} 2700$, Singapore), precalibrated with buffers of $\mathrm{pH} 4.0$ and 7.0.

Titratable acidity of the juice was measured by titrating with $0.1 \mathrm{~N} \mathrm{NaOH}$ and the results were expressed as percentage of citric acid [23]. Total soluble solids in the juice were determined with a hand digital refractometer (Digit-032) at $20^{\circ} \mathrm{C}$. The instrument was calibrated with distilled water before the analysis. The TSS values were expressed as ${ }^{\circ}$ Brix [24].

\subsubsection{Determination of Browning Degree}

The browning degree (BD) of pineapple juice was analyzed using a spectrophotometric method described by Roig et al. [25] with some modification. Pineapple juice was centrifuged with a refrigerated Centrifuge (Thermo Scientific Heraeus Megafuge $16 \mathrm{R}$, Germany) at $9000 \times \mathrm{g}$ at $4^{\circ} \mathrm{C}$ for $30 \mathrm{~min}$, and then passed through a $0.45 \mu \mathrm{m}$ cellulose nitrate membrane. The $\mathrm{BD}$ was determined by measuring the A (absorbance at $420 \mathrm{~nm}$ ) value using a spectrophotometer (UV-1600PC, Shanghai, China) at an ambient temperature $\left(20^{\circ} \mathrm{C} \pm 1{ }^{\circ} \mathrm{C}\right)$ with a $1 \mathrm{~cm}$ pathlength cell.

\subsubsection{Pectin Methylesterase Activity}

Pectin methylesterase (PME) activity was measured using the method adapted by Aguiló-Aguayo, et al. [26]. Briefly, $10 \mathrm{~mL}$ of pineapple juice was added to 40 $\mathrm{mL}$ of $1 \%$ citrus pectin solution in $2 \mathrm{~N} \mathrm{NaCl}$ and incubated at $30^{\circ} \mathrm{C} \pm 1^{\circ} \mathrm{C}$ in a water bath. When the temperature of the mixture reached $30^{\circ} \mathrm{C}$, the $\mathrm{pH}$ of the mixture was adjusted to 7.7 (optimum $\mathrm{pH}$ ) with $2 \mathrm{~N} \mathrm{NaOH}$ using a $\mathrm{pH}$ meter (Eutech Instruments, $\mathrm{pH} 2700$, Singapore). When a stable $\mathrm{pH}$ was obtained, 0.1 $\mathrm{mL}$ of $0.05 \mathrm{~N} \mathrm{NaOH}$ was added, and the time required for the $\mathrm{pH}$ to return to 7.7 was recorded. PME activity was calculated using Equation (1). PME activity was defined as the amount of enzyme that liberated $1.0 \mu$ mol equivalent of acid per minute under the assay conditions.

$$
\text { PME activity }=\frac{[\mathrm{NaOH}] \cdot V_{\mathrm{NaOH}}}{V_{\text {juice }} \cdot t^{\prime}}
$$

where $[\mathrm{NaOH}]$ is $\mathrm{NaOH}$ concentration $(0.05 \mathrm{~N}) ; V_{\mathrm{NaOH}}$ is the volume of $\mathrm{NaOH}$ used $(0.10 \mathrm{~mL}) ; V_{\text {juice }}$ is the volume of juice used $(10 \mathrm{~mL}) ;$ and $t^{\prime}$ is the time (in min) needed for the $\mathrm{pH}$ to return to 7.7 after the addition of $\mathrm{NaOH}$. 


\subsubsection{Total Phenolic Content}

The total phenolic content of pineapple juice was determined according to a method adapted by Alothman, et al. [27]. A dilute pineapple juice $(200 \mu \mathrm{L})$ was mixed with $1 \mathrm{~mL}$ of Folin-Ciocalteu's (FC) phenol reagent. The FC phenol reagent was prediluted 10 -fold with distilled water. After the pineapple juice-FC phenol reagent mixture was left at $30^{\circ} \mathrm{C} \pm 1{ }^{\circ} \mathrm{C}$ for $5 \mathrm{~min}, 800 \mu \mathrm{L}$ of sodium carbonate (7.5\%) was added. The solution was vortexed and allowed to stand for $2 \mathrm{~h}$ at room temperature. Then, the absorbance was measured at $765 \mathrm{~nm}$ with a spectrophotometer (UV-1600PC, Shanghai, China). The standard calibration curve was plotted using gallic acid $\left(y=0.043 \mathrm{x}-0.051 ; \mathrm{R}^{2}=0.994\right)$. The mean of three readings was used and the results expressed as $\mathrm{mg}$ of Gallic Acid Equivalents (GAE)/100 mL of juice.

\subsection{Microbial Analysis}

All samples were analysed for mesophilic, thermophilic, psychrophilic bacteria (total bacterial counts), also for yeasts, moulds and coliforms during 8 weeks of storage at room temperature. Juice samples $(1 \mathrm{~mL})$ were decimal diluted serially with sterile $1 \mathrm{mg} / \mathrm{mL}$ peptone water and appropriate dilutions were poured on to the respective plates. Total bacterial counts were determined on plate count agar (PCA; Merck, Darmstadt, Germany) following incubation at $35^{\circ} \mathrm{C}$ over 3 days for mesophilic bacteria, at $4^{\circ} \mathrm{C}$ over 7 days for psychrophilic bacteria and $55^{\circ} \mathrm{C}$ over 2 days for thermophilic bacteria. Yeasts and moulds were estimated on potato dextrose agar (Merck) and with incubation at $\left(28^{\circ} \mathrm{C} \pm 1^{\circ} \mathrm{C}\right)$ for 7 days. Coliforms were enumerated using Violet Red Bile Lactose Agar (Oxoid) at $\left(36^{\circ} \mathrm{C} \pm\right.$ $1^{\circ} \mathrm{C}$ ) for 48 hours. The number of individual colonies on plate was counted by visual observation in light. The actual CFU/100 $\mathrm{mL}$ of juice was then calculated using the following Equation (2):

$\mathrm{CFU} / 100 \mathrm{~mL}=($ Average number of colonies per plate/volume of sample $) \times$ dilution factor $(2)$

The microbial counts were expressed as log colony forming units (CFU)/100 $\mathrm{mL}$. All microbiological analyses for each batch were conducted at least in triplicate for each experiment.

\subsection{Statistical Analysis}

All experiments were performed in triplicate. Data were expressed as mean \pm standard deviation (SD). The Tukey's test and one-way analysis of variance (ANOVA) used for multiple comparisons by the SPSS 17.0 (SPSS, Chicago, USA). Difference was considered to be statistically significant if $P<0.05$.

\section{Results and Discussions}

\subsection{Physico-Chemical Analyses of Pineapple Juice}

\subsubsection{Effect of Treatments on pH, Total Soluble Solid (TSS) and Titrable Acidity (TA)}

Table 1 shows the changes in $\mathrm{pH}$, titratable acidity (TA) and total soluble solids (TSS) in pineapple juice during two months of storage. The $\mathrm{pH}$ values for the 
Table 1. Effect of treatments on pH, titrable acidity (TA) and total soluble solid (TSS).

\begin{tabular}{|c|c|c|c|c|c|c|}
\hline \multicolumn{7}{|c|}{ Time (days) } \\
\hline Parameters & Treatments & 0 & 15 & 30 & 45 & 60 \\
\hline \multirow{5}{*}{$\mathrm{pH}$} & Control & $4.10 \pm 0.03^{\mathrm{a}}$ & $3.60 \pm 0.09^{\mathrm{a}}$ & $3.39 \pm 0.03^{\mathrm{a}}$ & $3.29 \pm 0.01^{\mathrm{a}}$ & $3.21 \pm 0.05^{\mathrm{a}}$ \\
\hline & MP & $4.10 \pm 0.03^{\mathrm{a}}$ & $4.06 \pm 0.01^{\mathrm{b}}$ & $4.01 \pm 0.07^{\mathrm{b}}$ & $4.09 \pm 0.10^{\mathrm{b}}$ & $4.02 \pm 0.02^{\mathrm{b}}$ \\
\hline & US & $4.10 \pm 0.03^{\mathrm{a}}$ & $3.51 \pm 0.06^{\mathrm{a}}$ & $3.39 \pm 0.03^{\mathrm{a}}$ & $3.47 \pm 0.02^{\mathrm{a}}$ & $3.44 \pm 0.05^{\mathrm{a}}$ \\
\hline & UMP & $4.10 \pm 0.03^{\mathrm{a}}$ & $4.02 \pm 0.07^{\mathrm{b}}$ & $4.02 \pm 0.03^{\mathrm{b}}$ & $4.06 \pm 0.03^{\mathrm{b}}$ & $3.92 \pm 0.06^{\mathrm{b}}$ \\
\hline & TP & $4.10 \pm 0.03^{\mathrm{a}}$ & $4.01 \pm 0.02^{\mathrm{b}}$ & $4.05 \pm 0.05^{\mathrm{b}}$ & $4.02 \pm 0.06^{\mathrm{b}}$ & $3.99 \pm 0.09^{\mathrm{b}}$ \\
\hline \multirow{5}{*}{ TA } & Control & $8.83 \pm 1.03^{\mathrm{a}}$ & $21.60 \pm 1.07^{\mathrm{b}}$ & $23.27 \pm 1.13^{\mathrm{b}}$ & $23.60 \pm 1.02^{\mathrm{b}}$ & $23.90 \pm 1.06^{\mathrm{b}}$ \\
\hline & MP & $7.23 \pm 1.10^{\mathrm{a}}$ & $7.33 \pm 0.05^{\mathrm{a}}$ & $7.93 \pm 1.02^{\mathrm{a}}$ & $9.00 \pm 1.02^{\mathrm{a}}$ & $8.93 \pm 1.04^{\mathrm{a}}$ \\
\hline & US & $6.60 \pm 1.01^{\mathrm{a}}$ & $24.73 \pm 1.04^{\mathrm{b}}$ & $26.27 \pm 1.05^{\mathrm{b}}$ & $23.87 \pm 0.96^{\mathrm{b}}$ & $26.80 \pm 1.11^{\mathrm{b}}$ \\
\hline & UMP & $6.67 \pm 1.03^{\mathrm{a}}$ & $7.80 \pm 1.04^{\mathrm{a}}$ & $7.73 \pm 1.09^{\mathrm{a}}$ & $8.40 \pm 1.04^{\mathrm{a}}$ & $8.37 \pm 1.01^{\mathrm{a}}$ \\
\hline & TP & $9.20 \pm 1.06^{\mathrm{a}}$ & $7.47 \pm 1.10^{\mathrm{a}}$ & $7.60 \pm 1.05^{\mathrm{a}}$ & $7.40 \pm 0.83^{\mathrm{a}}$ & $7.40 \pm 1.05^{\mathrm{a}}$ \\
\hline \multirow{5}{*}{ TSS } & Control & $13.00 \pm 1.03^{\mathrm{a}}$ & $13.00 \pm 0.63^{\mathrm{a}}$ & $10.00 \pm 1.05^{\mathrm{a}}$ & $7.00 \pm 1.09^{\mathrm{a}}$ & $7.00 \pm 0.89^{\mathrm{a}}$ \\
\hline & MP & $15.00 \pm 1.18^{\mathrm{a}}$ & $16.00 \pm 0.78^{\mathrm{a}}$ & $16.00 \pm 1.10^{\mathrm{b}}$ & $16.00 \pm 1.02^{\mathrm{b}}$ & $15.00 \pm 1.05^{\mathrm{b}}$ \\
\hline & US & $14.00 \pm 1.06^{\mathrm{a}}$ & $14.50 \pm 1.09^{\mathrm{a}}$ & $15.00 \pm 0.67^{\mathrm{b}}$ & $15.50 \pm 1.11^{\mathrm{b}}$ & $15.00 \pm 1.03^{\mathrm{b}}$ \\
\hline & UMP & $15.00 \pm 0.97^{\mathrm{a}}$ & $15.00 \pm 1.21^{\mathrm{a}}$ & $16.00 \pm 0.94^{\mathrm{b}}$ & $16.00 \pm 1.07^{\mathrm{b}}$ & $15.50 \pm 1.06^{\mathrm{b}}$ \\
\hline & TP & $15.50 \pm 1.21^{\mathrm{a}}$ & $15.50 \pm 1.04^{\mathrm{a}}$ & $16.00 \pm 1.10^{\mathrm{b}}$ & $16.00 \pm 1.04^{\mathrm{b}}$ & $15.00 \pm 1.05^{\mathrm{b}}$ \\
\hline
\end{tabular}

Values are mean \pm standard deviation of triplicates. Data in same column with different letters are significantly different $(P<0.05)$. Control: fresh pineapple juice without any treatment; MP: juice subjected to mild heat treatment at $65^{\circ} \mathrm{C}$ for $15 \mathrm{~min}$; US: juice subjected to ultrasound treatment for $15 \mathrm{~min}$; UMP: ultrasound combined with mild heat pasteurization; TP: juice subjected to heat treatment at $80^{\circ} \mathrm{C}$ for $15 \mathrm{~min}$.

treated samples (MP, UMP and TP) varied between 4.10 and 3.95 suggesting the least significant differences $(P>0.05)$ among these values. The $\mathrm{pH}$ of the control and ultrasound treatment was found to decrease significantly $(P<0.05)$. Titrable acidity values evolved inversely compared to $\mathrm{pH}$ values during two months of storage. No significant change of TSS was observed for all samples except the control. In general, the acidity and the hydrogen ion concentration (indirectly the $\mathrm{pH}$ ) in any fruit product vary due to different types of biochemical reactions such as hydrolysis, oxidation, fermentation, and decomposition.

Increased acidity and lowest TSS in control sample might be due to spoilage and fermentation, resulted to the conversion of sugar to acids, carbon dioxide or alcohol [28]. The major sugar in pineapple juice was sucrose (86\%) and decreased during the fermentation. Carbohydrates are consumed during the fermentation due to the microbial growth. The $\mathrm{pH}$ decreased due to lactic acid production and sucrose hydrolysis occurred due to low $\mathrm{pH}$ values. These results were in agreement with the previous reports of Costa et al. [29]. Otherwise, in liquids, application of high power sonication creates the free radicals such as $\mathrm{H}^{+}$ and $\mathrm{OH}^{-}$radicals formed by the decomposition of water inside the cavities [21] [30]. That phenomenon might be responsible of the increased of pineapple juice acidity under the action of ultrasound treatment during the storage.

\subsubsection{Determination of Browning Degree (BD)}

Consumers consider product appearance to be the primary criterion for accep- 
tance. Color has been considered to play a key role in fruit juice, preference and overall acceptance. It may even influence taste thresholds, sweetness perception and pleasantness. In this regard, it is important to bear in mind that for a given treatment, color maintenance should be given consideration to ensure that the outcome of the final product meets consumer choice and acceptability.

Browning degree of different pineapple juice samples are increased by increasing storage time (Figure 1(a) and Figure 1(b)).

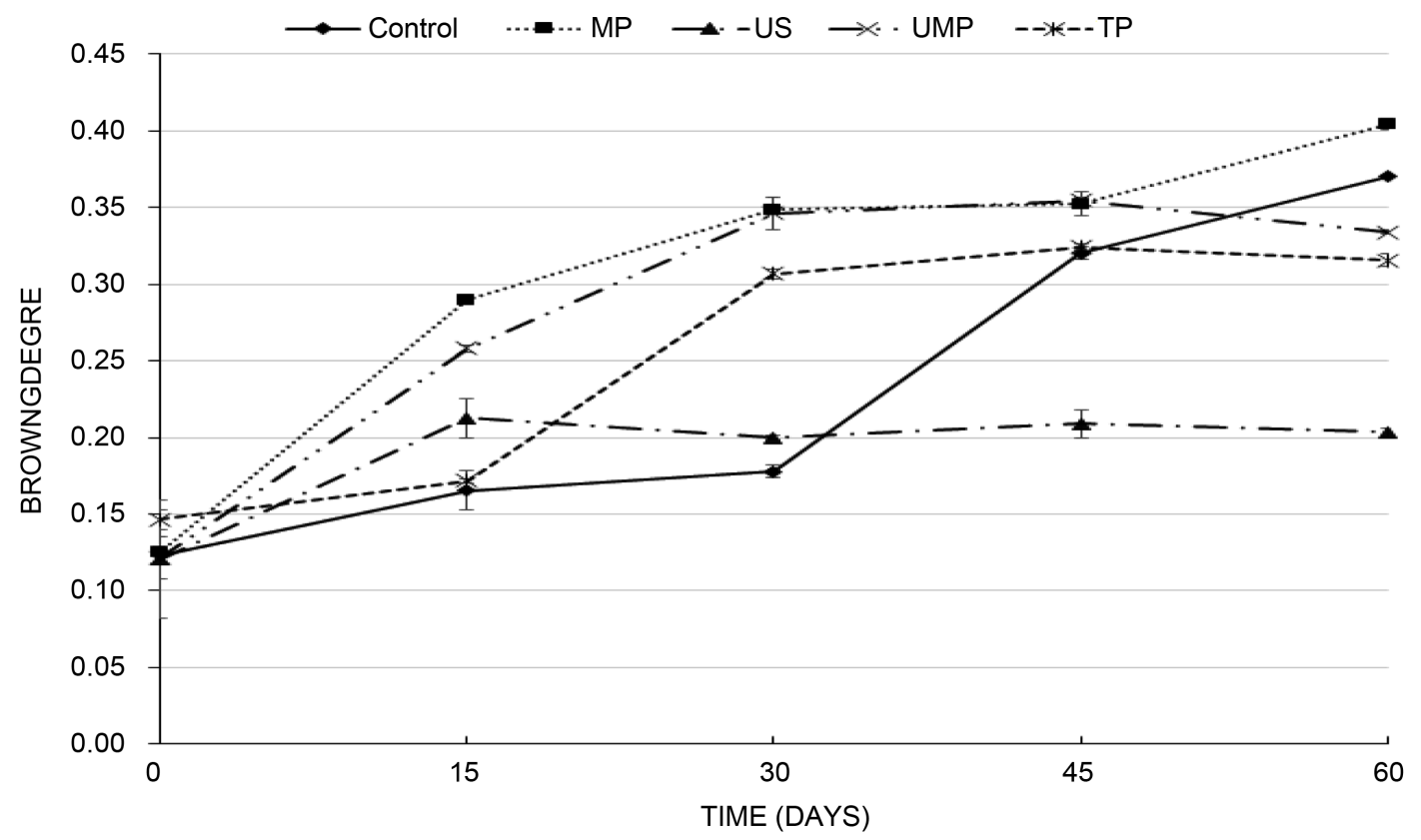

(a)

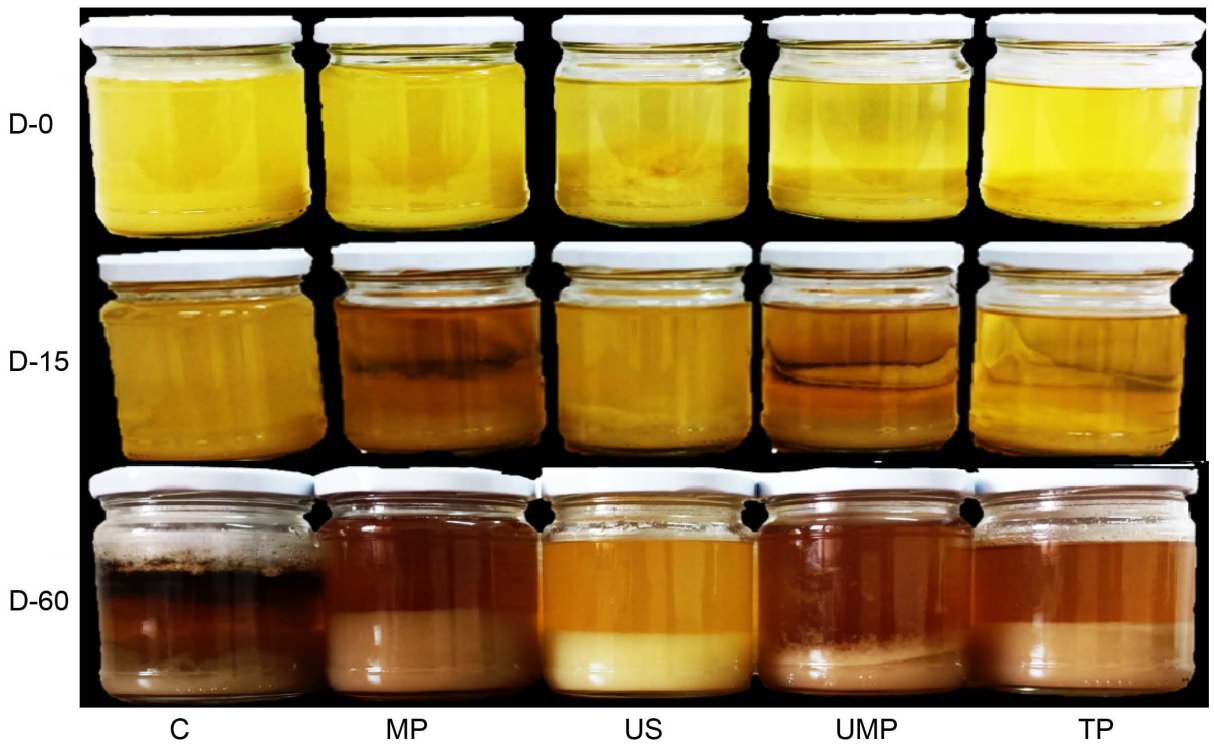

(b)

Figure 1. (a) and (b) Browning degree changes of pineapple juice at different types of treatment during storage at room temperature for 60 days. C: Control fresh pineapple juice without any treatment; MP: juice subjected to mild heat treatment at $65^{\circ} \mathrm{C}$ for $15 \mathrm{~min}$; US: juice subjected to ultrasound treatment for $15 \mathrm{~min}$; UMP: ultrasound combined with mild heat pasteurization; TP: juice subjected to heat treatment at $80^{\circ} \mathrm{C}$ for $15 \mathrm{~min}$. 
During the first 15 days of storage, the thermal pasteurization and control following by ultrasound treatments, showed the lowest browning degree compared to other treatments. When the storage progressed to day 60 , ultrasound sample showed significantly lower browning degree $(P<0.05)$. Spoilage of pineapple juice is not only encountered by microbial contamination but also by enzymatic degradation which is generally not accepted by the consumer [8]. The discoloring of fruit juice results from enzymatic browning, which is caused by the action of polyphenol oxidase (PPO) catalyzing oxidation of phenolic compounds [31] and pectin methylesterase (PME). PME is generally inactivated using conventional heat pasteurisation. The discoloration observed in thermal pasteurization sample will due to non-enzymatic browning through several biochemical reactions such as Maillard condensation, pigment destruction and caramelization of sugar [32] [33]. The lower browning observed in $\mathrm{U}$ treatment might be due to cavitation caused by sonication. Thus the mechanical effects and/or hydrogen peroxide $\left(\mathrm{H}_{2} \mathrm{O}_{2}\right)$ formation in pineapple juice during sonication are responsible for the retardation of browning. Hydrogen peroxide $\left(\mathrm{H}_{2} \mathrm{O}_{2}\right)$ has been demonstrated to exert an inhibitory effect on the browning to maintain whiteness of fruit and vegetable [34]. On the other hand, the lower browning observed in Control during the first 15 days of storage could be due to the carbon dioxide. In the presence of $\mathrm{O}_{2}$, the enzyme polyphenol oxydase (PPO) may oxidize these compounds to quinones which simultaneously polymerize into brown pigment [35]. Carbon dioxide inhibited the browning of pineapple juice and that PPO was competitively inhibited by $\mathrm{CO}_{2}$. This prevention of browning by $\mathrm{CO}_{2}$ probably was related to reduced $\mathrm{PPO}$ activity, since $\mathrm{CO}_{2}$ is a competitive inhibitor of PPO as demonstrated by Murr et al. [36].

\subsubsection{Pectin Methylesterase Activity}

Pectin methylesterase (PME), an ubiquitous enzyme found in plants, hydrolyses pectin resulting in decreased cloud stability and reduced viscosity due to pectin chain degradation. The effects of ultrasound and heat treatments on PME activity of pineapple juice during storage are shown in Figure 2.

The lower PME activity observed with US treatment, during storage could be due to the mechanical damage of the pectin methylesterase protein structure during sonication. On the other hand, the lower pectin methylesterase activity observed with thermal pasteurization treatment could be due to the heat pasteurisation. Pectin methylesterase is generally inactivated using conventional heat pasteurisation.

Studies show that the PME activity of pineapple was inactivated when heating temperature increased from $20^{\circ} \mathrm{C}$ to $90^{\circ} \mathrm{C}$ [37] [38]. Chang et al. [39] and Goh et al. [40] reported that the PME activity in pineapple was reduced by heat pasteurisation.

\subsubsection{Total Phenolic Content}

The effects of different treatments during the storage time on the total phenolic content of pineapple juice are shown in Figure 3. All samples showed significant 


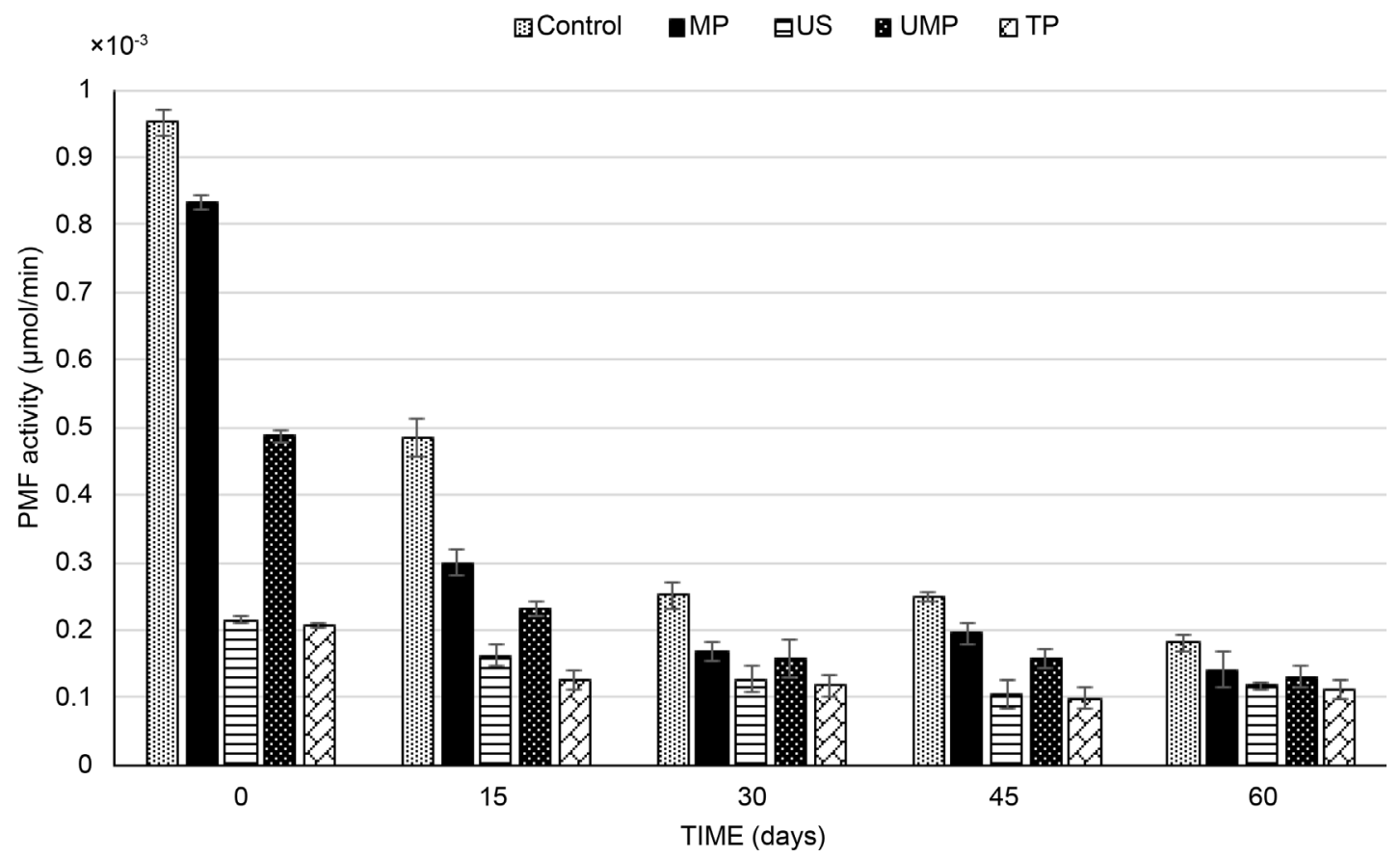

Figure 2. Pectin methylesterase activity of pineapple juice during storage at room temperature for 60 days under different treatments.

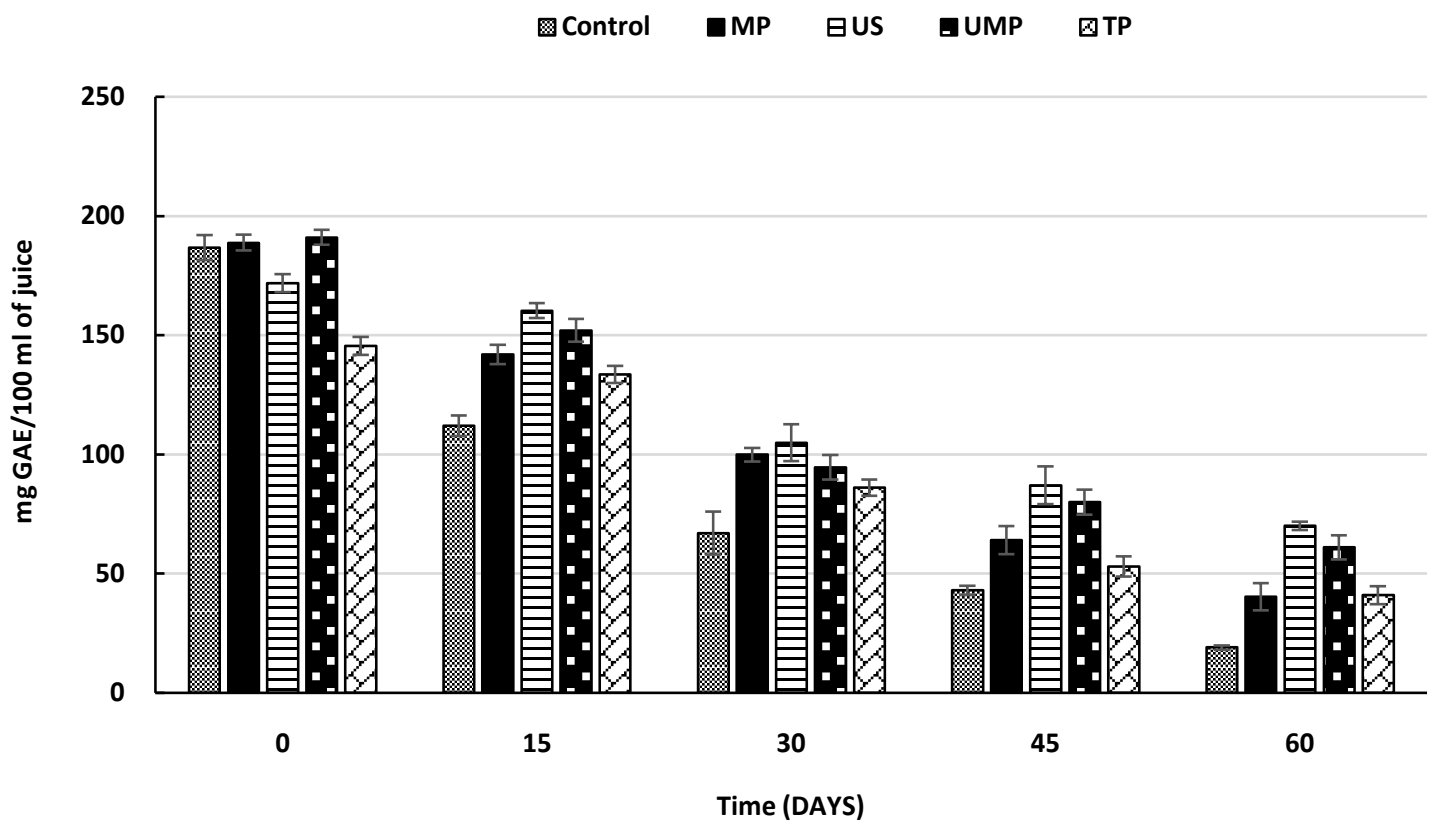

Figure 3. Changes in total phenolic content in pineapple juice during storage at room temperature for 60 days under different treatments.

$(P<0.05)$ decrease on the total phenolic content during storage. There was a significant difference between control and treated samples at end of storage. Ultrasound followed by ultrasound combined with mild heat pasteurization treatments were effective in retaining the total phenolic content of pineapple juice as compared to the thermal treatment or the untreated juice sample at room temperature during 60 days of storage. The results confirmed that the application of 
ultrasound treatment preserved the total phenolic level of fruit juices during the storage. Similar results have been reported for the studies of different fruit and vegetable juices [41]. The changes in the levels of phenolic compounds indicate the deteriorating quality of fruit products due to browning, formation of hazes and sediments [42]. The decrease in the phenolic content of the samples during storage usually has effects on the color parameters. The lower total phenolic content observed with MP and TP treatments, during storage could be due to thermal pasteurization. According to Goh et al. 2012, [40], conventional heat pasteurisation is able to inactivate pectin methylesterase in pineapple juice, it compromises the heat sensitive phenolic compounds. Thus, at a higher temperature like $70^{\circ} \mathrm{C}$, thermal degradation of total phenolic was faster resulting to a lower amount of bioactive total phenolic in the sample [43]. Our results showed direct correlation between phenolic compounds and browning degree.

\subsection{Microbial Analysis}

Organisms which are usually responsible for spoilage of fruit juice include gram-negative, psychrotrophic bacteria, yeast and moulds. Figures 4(a)-(d) shows mesophilic, psychrophilic, yeasts and moulds counts of pineapple juice treated with US, MP, UMP, TP and control stored for a period of 60 days at room temperature.

Gradual growth of all microorganisms was seen during storage in all samples. However, some treatments retarded the microbial growth more than others. Generally, yeasts and moulds were present in relatively lower numbers during the storage. Coliforms and thermophilic were not founded in any samples. The highest amount of microorganisms was observed in control samples. Thermal pasteurization (TP) followed by ultrasound combined with mild heat pasteurization and ultrasound treatment, in increasing order, were found to be effective in delaying microbial growth in pineapple juice. Thermal pasteurization treatments were effective in retaining the microbial growth in pineapple juice during storage at room temperature. Unfortunately, due to the high temperature used in the process, the nutritional and sensory properties of the pasteurized juice were somewhat altered. Many researchers have also demonstrated that heating is the most widely accepted technique used for inactivating microorganisms in food, however there can be a significant change in the functional properties and contents of food, which tends to reduce the product quality and freshness [41] [43] [44] [45]. The lowest amounts of microorganisms found in UMP and US treated samples might be due to ultrasound process that creates the cavitation caused by the changes in pressure responsible for the destruction of bacteria. The mechanism of microbial destruction is mainly due to thinning of cell membranes, localized heating and production of free radicals [46] [47]. These observations are in agreement with those authors reported that ultrasound can reduce the microbial levels on strawberry [48] and plum fruit [49]. The results of a research carried out by Dolatowski et al. [50] proved that ultrasound processing is having a significant influence on microbiological contamination of meat. 


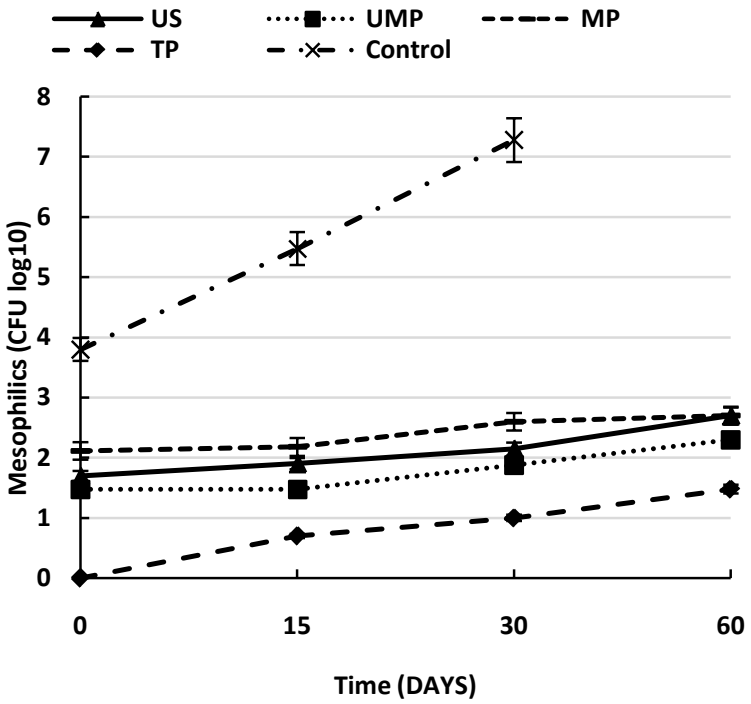

(a)

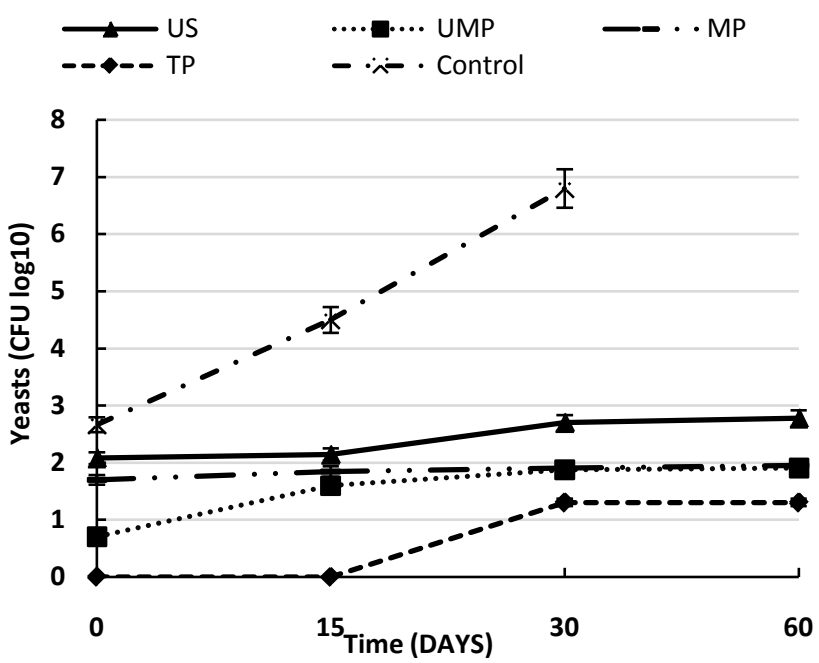

(c)

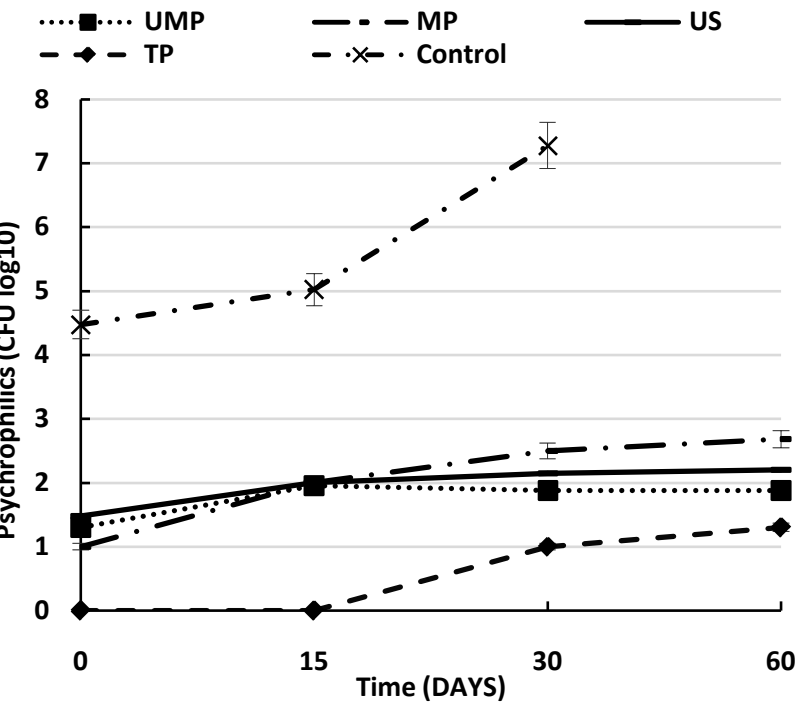

(b)
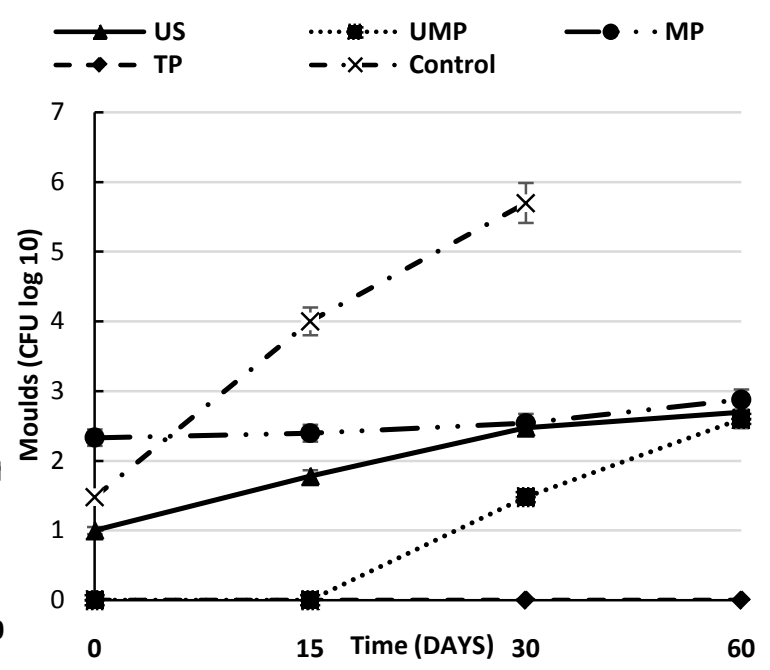

(d)

Figure 4. Microbial counts in pineapple juice during storage at room temperature for 60 days under different treatments ((a)-mesophilics, (b)-psychrophilics, (c)-yeasts, (d)-moulds).

\section{Conclusion}

Compared to the untreated (control) samples, treated samples had significantly $(P<0.05)$ longer shelf-life. The ultrasound and combination of non-thermal methods are a new approach for preservation of fruit juices that can enhance the microbiological safety while having lower impact on the organoleptic and nutrient properties of juices in comparison with the thermal processing.

\section{Acknowledgements}

The authors would like to thank Dr. Abdou Madjid O. Amoussa, for technical assistance.

\section{References}

[1] Cao, G., Sofic, E. and Prior, R.L. (1996) Antioxidant Capacity of Tea and Common 
Vegetables. Journal of Agricultural and Food Chemistry, 44, 3426-3431. https://doi.org/10.1021/jf9602535

[2] Wang, H., Cao, G. and Prior, R.L. (1996) Total Antioxidant Capacity of Fruits. Journal of Agricultural and Food Chemistry, 44, 701-705. https://doi.org/10.1021/jf950579y

[3] Larson, R.A. (1988) The Antioxidants of Higher Plants. Phytochemistry, 27, 969978. https://doi.org/10.1016/0031-9422(88)80254-1

[4] Dragsted, L.O. (2003) Antioxidant Actions of Polyphenols in Humans. International Journal for Vitamin and Nutrition Research, 73, 112-119. https://doi.org/10.1024/0300-9831.73.2.112

[5] Hale, L.P., Greer, P.K., Trinh, C.T. and James, C.L. (2005) Proteinase Activity and Stability of Natural Bromelain Preparations. International Immunopharmacology, 5, 783-793. https://doi.org/10.1016/j.intimp.2004.12.007

[6] Taussig, S.J. and Batkin, S. (1988) Bromelain, the Enzyme Complex of Pineapple (Ananas comosus) and Its Clinical Application: An Update. Ethnopharmacol, 22, 191-203. https://doi.org/10.1016/0378-8741(88)90127-4

[7] Hale, L.P. (2004) Proteolytic Activity and Immunogenicity of Oral Bromelain within the Gastrointestinal Tract of Mice. International Immunopharmacology, 4, 255-264. https://doi.org/10.1016/j.intimp.2003.12.010

[8] Chakraborty, S., Rao, P.S. and Mishra, H.N. (2014) Effect of pH on Enzyme Inactivation Kinetics in High-Pressure Processed Pineapple (Ananas comosus L.) Puree Using Response Surface Methodology. Food and Bioprocess Technology, 7, 3629-3645. https://doi.org/10.1007/s11947-014-1380-0

[9] Shomer, R., Cogan, U. and Mannheim, C.H. (1994) Thermal Death Parameters of Orange Juice and Effect of Minimal Heat Treatment and Carbon Dioxide on ShelfLife. Journal of Food Processing and Preservation, 18, 305-315. https://doi.org/10.1111/j.1745-4549.1994.tb00254.x

[10] Devlieghere, F., Vermeiren, L. and Debevere, J. (2004) New Preservation Technologies: Possibilities and Limitations. International Dairy Journal, 14, 273-285. https://doi.org/10.1016/j.idairyj.2003.07.002

[11] Jeyamkondan, S., Jayas, D.S. and Holley, R.A. (1999) Pulsed Electric field Processing of Foods: A Review. Journal of Food Protection, 62, 1088-1096. https://doi.org/10.4315/0362-028X-62.9.1088

[12] Bhat, R., Ameran, S.B., Karim, A.A. and Liong, M.T. (2011) Quality Attributes of Starfruit (Averrhoa carambola L.) Juice Treated with Ultraviolet Radiation. Food Chemistry, 127, 641-644. https://doi.org/10.1016/j.foodchem.2011.01.042

[13] Tiwari, B.K., Muthukumarappan, K., O’Donnell, C.P. and Cullen, P.J. (2009) Inactivation Kinetics of Pectin Methylesterase and Cloud Retention in Sonicated Orange Juice. Innovative Food Science and Emerging Technologies, 10, 166-171. https://doi.org/10.1016/j.ifset.2008.11.006

[14] Valero, M., Recrosio, N., Saura, D., Muñoz, N., Martí, N. and Lizama, V. (2007) Effects of Ultrasonic Treatments in Orange Juice Processing. Journal of Food Engineering, 80, 509-516. https://doi.org/10.1016/j.jfoodeng.2006.06.009

[15] O’Donnell, C.P., Tiwari, B.K., Bourke, P. and Cullen, P.J. (2010) Effect of Ultrasonic Processing on Food Enzymes of Industrial Importance. Trends in Food Science \& Technology, 21, 358-367. https://doi.org/10.1016/j.tifs.2010.04.007

[16] Cheng, L.H., Soh, C.Y., Liew, S.C. and Teh, F.F. (2007) Effects of Sonication and Carbonation on Guava Juice Quality. Food Chemistry, 104, 1396-1401.

https://doi.org/10.1016/j.foodchem.2007.02.001 
[17] Tiwari, B.K., O’Donnell, C.P.O., Patras, A. and Cullen, P.J. (2008) Anthocyanin and Ascorbic Acid Degradation in Sonicated Strawberry Juice. Journal of Agriculture and Food Chemistry, 56, 10071-10077. https://doi.org/10.1021/jf801824v

[18] Salleh-Mack, S.Z. and Roberts J.S. (2007) Ultrasound Pasteurization: The Effects of Temperature, Soluble Solids, Organic Acids and $\mathrm{pH}$ on the Inactivation of Escherichia coli ATCC 25922. Ultrasonics Sonochemistry, 14, 323-329. https://doi.org/10.1016/j.ultsonch.2006.07.004

[19] Ugarte-Romero, E., Feng, H., Martin, S.E., Cadwallader, K.R. and Robinson, S.J. (2006) Inactivation of Escherichia coli with Power Ultrasound in Apple Cider. Journal of Food Science, 71, 102-108. https://doi.org/10.1111/j.1365-2621.2006.tb08890.x

[20] Baumann A.R., Martin S.E. and Feng H. (2005) Power Ultrasound Treatment of Listeria Monocytogenes in Apple Cider. Journal of Food Protection, 68, 2333-2340. https://doi.org/10.4315/0362-028X-68.11.2333

[21] Piyasena, P., Mohareb, E. and McKellar, R.C. (2003) Inactivation of Microbes Using Ultrasound. International Journal of Food Microbiology, 87, 207-216. https://doi.org/10.1016/S0168-1605(03)00075-8

[22] Jiranek, V., Grbin, P., Yap, A., Barnes, M. and Bates, D. (2008) High Power Ultrasonics as a Novel Tool Offering New Opportunities for Managing Wine Microbiology, Biotechnology Letters, 30, 1-6. https://doi.org/10.1007/s10529-007-9518-Z

[23] James, C.S. (1995) Analytical Chemistry of Foods. Springer, New York. https://doi.org/10.1007/978-1-4615-2165-5

[24] Naresh, K., Varakumar, S., Variyar, P.S., Sharma, A. and Reddy, O.V.S. (2014) Impact of $\gamma$-Irradiation on Antioxidant Capacity of Mango (Mangifera indica L.) Wine from Eight Indian Cultivars and the Protection of Mango Wine against DNA Damage Caused by Irradiation. Process Biochemistry, 49, 1819-1830. https://doi.org/10.1016/j.procbio.2014.07.015

[25] Roig, M.G., Bello, J.F., Rivera, Z.S. and Kennedy, J.F. (1999) Studies on the Occurrence of Nonenzymatic Browning during Storage of Citrus Juice. Food Research International, 32, 609-619. https://doi.org/10.1016/S0963-9969(99)00128-3

[26] Aguiló-Aguayo, I., Soliva-Fortuny, R. and Martín-Belloso, O. (2009) Changes in Viscosity and Pectolytic Enzymes of Tomato and Strawberry Juices Processed by High-Intensity Pulsed Electric fields. International Journal of Food Science and Technology, 44, 2268-2277. https://doi.org/10.1111/j.1365-2621.2009.02068.x

[27] Alothman, M., Bhat, R. and Karim, A.A. (2009) Antioxidant Capacity and Phenolic Content of Selected Tropical Fruits from Malaysia, Extracted with Different Solvents. Food Chemistry, 115,785-788. https://doi.org/10.1016/j.foodchem.2008.12.005

[28] Bhardwaj, R.L. and Pandey, S. (2011) Juice Blends-A Way of Utilization of UnderUtilized Fruits, Vegetables, and Spices: A Review. Critical Reviews in Food Science and Nutrition, 51, 563-570. https://doi.org/10.1080/10408391003710654

[29] Costa, M.G., Fonteles, T.V., de Jesus, A.L. and Rodrigues, S. (2013) Sonicated Pineapple Juice as Substrate for $L$. casei Cultivation for Probiotic Beverage Development: Process Optimisation and Product Stability. Food Chemistry, 139, 261-266. https://doi.org/10.1016/j.foodchem.2013.01.059

[30] Cansino, N.C., Carrera, G.P., Rojas, Q.Z., Olivares, L.D., García, E.A. and Moreno, E.R. (2013) Ultrasound Processing on Green Cactus Pear (Opuntia ficus Indica) Juice: Physical, Microbiological and Antioxidant Properties. Journal of Food 
Processing and Technology, 4, 1-6.

[31] Joslyn, M.A. and Ponting, J.D. (1951) Enzyme-Catalyzed Oxidative Browning of Fruit Products. Advances in Food Research, 3, 1-44. https://doi.org/10.1016/S0065-2628(08)60258-X

[32] Ibarz, A., Pagan, J. and Garza, S. (2000) Kinetic Models of Non-Enzymatic Browning in Apple Puree. Journal of the Science of Food and Agriculture, 80, 11621168 . https://doi.org/10.1002/1097-0010(200006)80:8<1162::AID-JSFA613>3.0.CO;2-Z

[33] Landl, A., Abadias, M., Sárraga, C., Viñas, I. and Picouet, P.A. (2010) Effect of High Pressure Processing on the Quality of Acidified Granny Smith Apple Purée Product. Innovative Food Science and Emerging Technologies, 11, 557-564. https://doi.org/10.1016/j.ifset.2010.09.001

[34] Sapers G.M., Miller R.L., Pilizota V. and Kamp, F. (2001) Shel-Flife Extension of Fresh Mushrooms (Agaricus bisporus) by Application of Hydrogen Peroxide and Browning Inhibitors. Journal of Food Science, 66, 362-366. https://doi.org/10.1111/j.1365-2621.2001.tb11347.x

[35] Espin, J.C., Jolivet, S. and Wichers, H.J. (1998) Inhibition of Mushroom Polyphenol Oxidase by Agaritine. Journal of Agricultural and Food Chemistry, 46, 2976-2980. https://doi.org/10.1021/jf9802732

[36] Murr, D.P. and Morris, L.L. (1974) Influence of $\mathrm{O}_{2}$ and $\mathrm{CO}_{2}$ on O-Diphenol Oxidase Activity in Mushroom. Journal of the American Society for Horticultural Science, 99, 155-158.

[37] Gupta, P., Maqbool, T. and Saleemuddin, M. (2007) Oriented Immobilization of Stem Bromelain via the Lone Histidine on a Metal Affinity Support. Journal of Molecular Catalysis B: Enzymatic, 45, 78-83. https://doi.org/10.1016/j.molcatb.2006.12.002

[38] Poh, S.S. and Abdul Majid, F.A. (2011) Thermal Stability of Free Bromelain and Bromelainpolyphenol Complex in Pineapple Juice. International Food Research Journal, 18, 1051-1060.

[39] Sew, C., Ghazali, H., Martín-Belloso, O. and Noranizan, M. (2014) Effects of Combining Ultraviolet and Mild Heat Treatments on Enzymatic Activities and Total Phenolic Contents in Pineapple Juice. Innovative Food Science and Emerging Technologies, 26, 511-516. https://doi.org/10.1016/j.ifset.2014.05.008

[40] Goh, S.G., Noranizan, M., Leong, C.M., Sew, C.C. and Sobhi, B. (2012) Effect of Thermal and Ultraviolet Treatments on the Stability of Antioxidant Compounds in Single Strength Pineapple Juice Throughout Refrigerated Storage. International Food Research Journal, 19, 1131-1136.

[41] Khandpur, P. and Gogate, P.R. (2015) Effect of Novel Ultrasound Based Processing on the Nutrition Quality of Different Fruit and Vegetable Juices. Ultrasonics Sonochemistry, 27, 125-136. https://doi.org/10.1016/j.ultsonch.2015.05.008

[42] Macheix, J., Fleuriet, A. and Billot, J. (1990) Fruit Phenolics. CRC Press, Boca Raton, 378.

[43] Chakraborty, S., Rao, P. and Mishra, H. (2015) Effect of Combined High Pressure-Temperature Treatments on Color and Nutritional Quality Attributes of Pineapple (Ananas comosus L.) Puree. Innovative Food Science and Emerging Technologies, 28, 10-21. https://doi.org/10.1016/j.ifset.2015.01.004

[44] Shamsudin, R., Noranizan, M.A., Yap, P.Y. and Mansor, A. (2014) Effect of Repetitive Ultraviolet Irradiation on the Physic-Chemical Properties and Microbial Stability of Pineapple Juice. Innovative Food Science and Emerging Technologies, 
23, 114-120. https://doi.org/10.1016/j.ifset.2014.02.005

[45] Shamsudin, R., Chia, S.L., Mohd Adzahan, N. and Wan Daud, W.R. (2013) Rheological Properties of Ultraviolet-Irradiated and Thermally Pasteurized Yankee Pineapple Juice. Journal of Food Engineering, 116, 548-553.

https://doi.org/10.1016/j.jfoodeng.2012.12.031

[46] Butz, P. and Tauscher, B. (2002) Emerging Technologies: Chemical Aspects. Food Research International, 35, 279-284. https://doi.org/10.1016/S0963-9969(01)00197-1

[47] Fellows, P. (2000) Food Processing Technology: Principles and Practice. 2nd Edition, CRC Press, New York.

[48] Cao, S., Hu, Z. and Pang, B. (2010) Optimization of Postharvest Ultrasonic Treatment of Strawberry Fruit. Postharvest Biology and Technology, 55, 150-153. https://doi.org/10.1016/j.postharvbio.2009.11.002

[49] Chen, Z. and Zhu, C. (2011) Combined Effects of Aqueous Chlorine Dioxide and Ultrasonic Treatments on Postharvest Storage Quality of Plum Fruit (Prunus salicina L.). Postharvest Biology and Technology, 61, 117-123.

https://doi.org/10.1016/j.postharvbio.2011.03.006

[50] Dolatowski, Z.J. and Stasiak, D.M. (2002) Czystosc mikrobiologiczna miesa i szynki parzonej poobróbce ultradzwiekowej [Bacterial Contamination of Meat and Meat Products after Ultrasound Treatment]. Acta Scientiarum Polonorum Technologia Alimentaria, 1, 55-65. (In Polish)

Submit or recommend next manuscript to SCIRP and we will provide best service for you:

Accepting pre-submission inquiries through Email, Facebook, LinkedIn, Twitter, etc. A wide selection of journals (inclusive of 9 subjects, more than 200 journals)

Providing 24-hour high-quality service

User-friendly online submission system

Fair and swift peer-review system

Efficient typesetting and proofreading procedure

Display of the result of downloads and visits, as well as the number of cited articles

Maximum dissemination of your research work

Submit your manuscript at: http://papersubmission.scirp.org/

Or contact fns@scirp.org 